\title{
International Journal of Research and Applied Technology
}

1(1)(2021) 43-48

Journal homepage: https://ojs.unikom.ac.id/index.php/injuratech

\section{Website Analysis as a Media for Healthy Living Digital Campaign}

\author{
L Wulantika ${ }^{*}$, A Ragatodi'2, M A Sya'bani ${ }^{3}$, R Nugraha ${ }^{4}$ \\ 1Departemen Manajemen, Universitas Komputer Indonesia, Indonesia \\ 2,3Departemen Ilmu Komunikasi, Universitas Komputer Indonesia, Indonesia \\ 4Departemen Teknik Elektro, Universitas Komputer Indonesia, Indonesia \\ Email: *lita.wulantika@email.unikom.ac.id
}

\begin{abstract}
A website is a collection of information or a collection of pages commonly accessed via the internet. One of them is the Healthy Living Campaign Website. This research aims to support the community in carrying out a healthy lifestyle by providing information to implement a healthy lifestyle. However, the source of information from the Healthy Living Campaign Website is said to be incomplete. For that, a maximum evaluation is needed. The research used descriptive and qualitative analysis methods. The results obtained indicate that the Healthy Living Campaign Website has advantages and disadvantages in terms of information. This result research is The Healthy Living Together Activity Website has several views in its design. It is due to several factors, such as the views that influence the design of the website. However, in general, the positive impact could be related to the information conveyed through the Healthy Living Campaign Website.
\end{abstract}

\section{Introduction}

The development of information technology, which is currently growing rapidly, has made it easier for the community, especially nowadays, where the internet is no longer strange. To get information through the internet media, the public can easily access it anywhere. One of the facilities used to get that information is through the website [1]. Because the website is a media that contains text, visuals, and audio. Therefore, community can easily understand the information needed. In developing a web, several things need to be considered to attract internet users' attention [2]. Especially in today's era, many webs have sprung up in the internet world [3].

To attract the attention of internet users, a good web design is needed here. A good web design can attract internet users and make internet users come back to visit the website [4]. When creating a good website, several important points can be needed, such as Usability, Navigation System, Visual Design, Content, Compatibility, Length of Process, Functionality, Accessibility, and Interactivity [5]. In the website's current development, many web design views can be said to have not met the requirements for designing a good and correct website. So often, several mistakes occur in designing a website [6]. It can interfere with the criteria for 


\section{International Journal of Research and Applied Technology}

1(1)(2021) 43-48

Journal homepage: https://ojs.unikom.ac.id/index.php/injuratech

retaining the information needed [7]. A website is a collection of web pages connected, and their data is tied together. A website consists of pages that are often called the home page [8]. A digital campaign will be designed later to become one of the media most popular with the public to reduce the pressure on people's lives in urban areas with relaxation activities and other benefits.

It is revealed that the quality of a website affects the level of user satisfaction. In this study, if the higher the website's quality, the more users will access it [9]. This paper discusses the information needs of the website. First, an online survey was conducted to determine the visual appeal of the website page. To improve on the invention. This case study tracking performs the browsing of the pages of this website. Knowing what attracts the public's attention is to choose website pages and interesting features to see and use [10]. This website is a collection of information or a collection of pages commonly accessed via the internet. One of them is the Healthy Living Campaign on the website. This website aims to support the community in carrying out a healthy lifestyle by providing information to implement a healthy lifestyle.

\section{Method}

The research method used a descriptive qualitative approach and data collection techniques by conducting interviews, interviews, savings, and observations. Qualitative methods seek to understand and interpret the meaning of an event of interaction with human behavior in a particular situation according to the researcher's perspective. The variables used in this study were seven of thirteen variables.

\section{Results and Discussion}

In technological advances, people can easily find information about what they need, such as looking for information through a website. Still, sometimes the website does not provide information about what is needed [11].

With a healthy living website with the community, people can easily get information about a healthy lifestyle. As shown in Figure 1. The only way is to enter your email account and password, then log in. People can get information about healthy lifestyles. It is considered very easy for the community because only by following a few steps, the public can get this information. 


\section{International Journal of Research and Applied Technology}

$1(1)(2021) 43-48$

Journal homepage: https://ojs.unikom.ac.id/index.php/injuratech

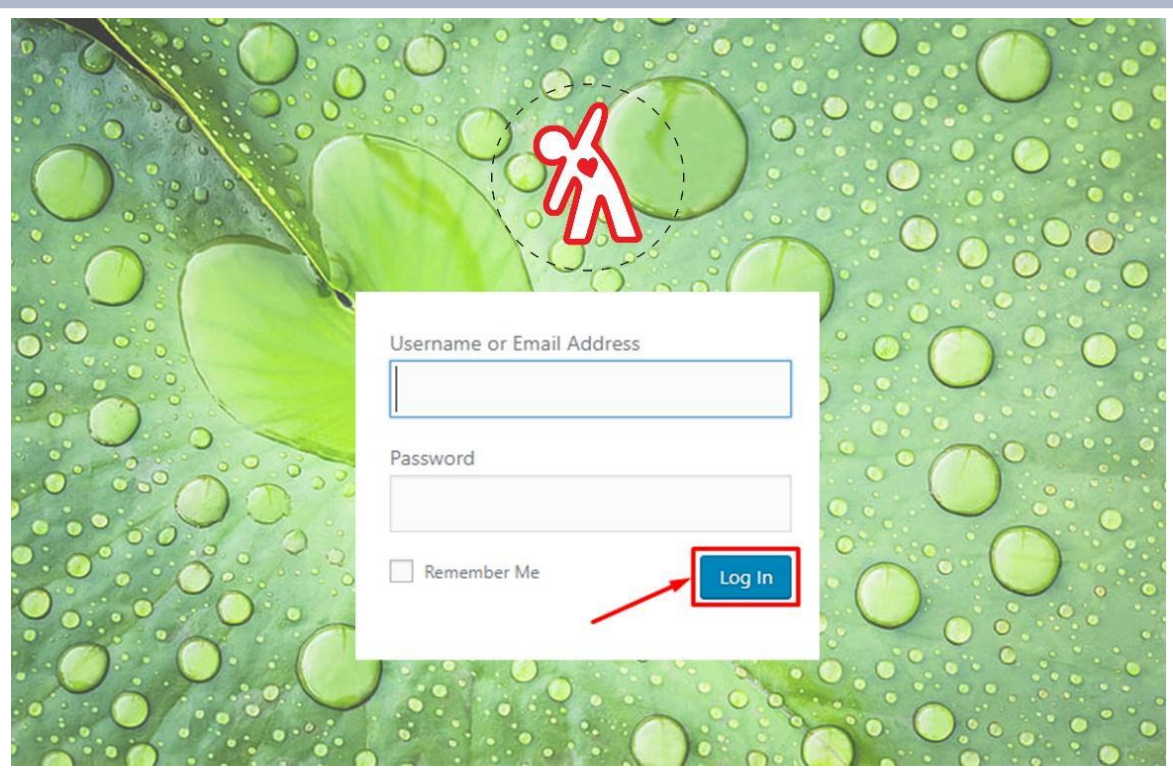

Figure 1. Login Access Website

Healthy Living Together website design analysis using books "Principles of Beautiful Web Design" to find out what the public thinks about the website for healthy living together Figure 2 .

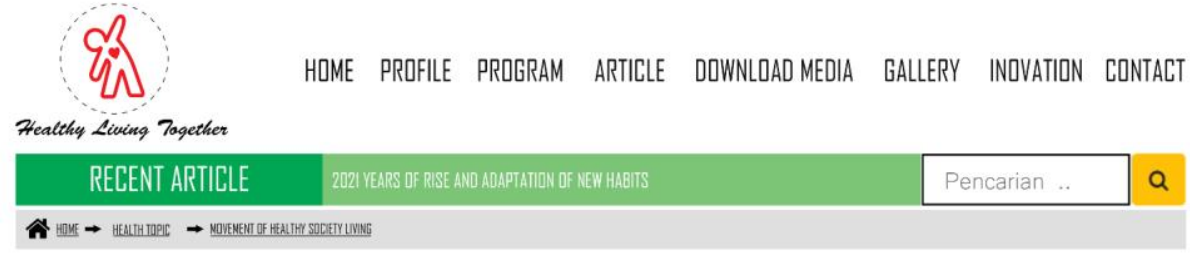

\section{Stay Healthy, Stay Motivated.}

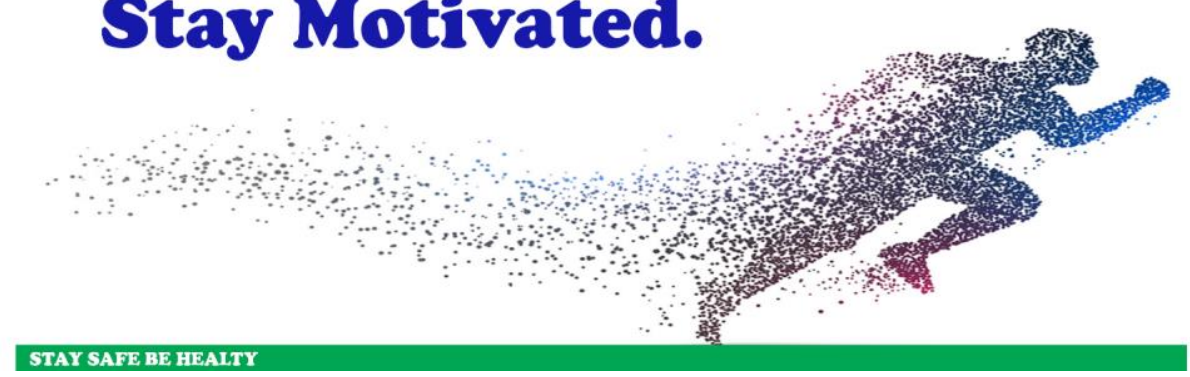

Figure 2. Healthy Living Together

Stay Healthy, Stay Motivated is the Healthy living together website's tagline, which is this website, is aimed at people who want to live a healthy life. 


\section{International Journal of Research and Applied Technology}

$1(1)(2021) 43-48$

Journal homepage: https://ojs.unikom.ac.id/index.php/injuratech

- Defining Good Design

In this variable, Healthy Living Together is considered a good website. The Healthy Living together web has used a template that can guide readers to focus on content. The web of healthy living together has also used a white patterned template with the meaning of cleanliness, which is the color of the web's identity of healthy living together.

The navigation is to be standard because the navigation key is in capital letters to easily see navigation.

The web campaign for healthy living is straightforward to recognize because it is dominated by white patterns, making these patterns the distinctive characteristics of the web.

\section{- Website Page Anatomy}

In this variable, the web design used fully follows the principles of a well-defined web page. It can be seen in the sub variable. The Healthy Life Together website has a containing block centered in the middle. The logo part is very clear. Located in the upper left corner, the navigation on this website also forms three colors. The content is in the middle of the web display so that tourists can immediately read content from the web. The white footer is very well used for characterizing the footer on that part of the web.

\section{- $\quad$ Grid Theory}

The Healthy Life Together website has used the variable grid theory because it can be seen on the web that has used or has conditions with a sign that produces three sections as an alignment guide to the identity, content, navigator, and footer sections. It is also the same as what is done on the Healthy Living website together.

\section{- Balance}

This website used asymmetrical balance so that this website looks neat because of the horizontal balance. It is also seen on the right and left, which does not have any elements so that this web looks neat, simple, and elegant.

- Unity

Divided by this variable, the Healthy Life Together website uses a repetition approach to combine all content. The marking used is to use a color pattern on each part of the website, such as green and white, to indicate the top, content, and bottom.

- Bread And Butter Layout

In this section, the Healthy Living Together website has a good layout. This website uses three navigation columns, which means that the three-column layout has a large center column containing images and is flanked by two small navigation columns.

- Fresh Trend

Healthy Living Together website using Fresh trend variable in the appearance of its website design. It is the expansive footer navigation, which includes contact data, navigation, and expanded web navigation.

Some of the questionnaires were made about the Joint Healthy Living Activity Website. We gave this interview to as many as ten interview participants. The results of the interview were obtained in table 1 below as follows: 


\section{International Journal of Research and Applied Technology}

$1(1)(2021) 43-48$

Journal homepage: https://ojs.unikom.ac.id/index.php/injuratech

Table 1. Questionnaires

\begin{tabular}{|c|c|c|}
\hline No & Question & Answer \\
\hline 1 & $\begin{array}{l}\text { What do you think about the } \\
\text { appearance of the Healthy Living } \\
\text { Together website? }\end{array}$ & $\begin{array}{l}\text { Very interesting, especially on the } \\
\text { front, the image used has its own } \\
\text { charm for the viewer }\end{array}$ \\
\hline 2 & $\begin{array}{l}\text { Do the features on the Healthy Living } \\
\text { Together website have good } \\
\text { information? }\end{array}$ & $\begin{array}{l}\text { Yes, it is very helpful for us to know } \\
\text { better how to live a healthy lifestyle }\end{array}$ \\
\hline 3 & $\begin{array}{l}\text { What do you think about the Healthy } \\
\text { Living Together website? }\end{array}$ & $\begin{array}{l}\text { Some people really like this website, } \\
\text { because the content is quite helpful for } \\
\text { people's needs }\end{array}$ \\
\hline 4 & $\begin{array}{l}\text { Do you think the Healthy Life Together } \\
\text { website will be effective as information } \\
\text { for the public? This website can be said } \\
\text { to be quite effective in the community, } \\
\text { especially regarding information about } \\
\text { health }\end{array}$ & $\begin{array}{l}\text { Do you think the Healthy Life } \\
\text { Together website will be effective as } \\
\text { information for the public? This } \\
\text { website can be said to be quite effective } \\
\text { in the community, especially } \\
\text { regarding information about } \\
\text { health }\end{array}$ \\
\hline
\end{tabular}

Table 1 aims for the public to know the Healthy Living Together Website, how the website looks, whether it is interesting or not, and the public can also find out information to have a healthy lifestyle.

\section{Conclusion}

The Healthy Living Together Activity Website has several views in its design. It is due to several factors, such as the views that influence the design of the website. However, the entire website has paid enough attention to long-term aspects, even though some still lack some approaches. Likewise, the people who use and view the Healthy Life Together website feel comfortable with this website because it is considered useful information, especially for people who want to be healthy.

\section{References}

[1] Kaur, S., Kaur, K., \& Kaur, P. 2016, March. Analysis of website usability evaluation methods. In 2016 3rd International Conference on Computing for Sustainable Global Development (INDIACom), pp. 1043-1046.

[2] Garett, R., Chiu, J., Zhang, L., \& Young, S. D. 2016. A literature review: website design and user engagement. Online journal of communication and media technologies, 6(3), 1

[3] Hasugian, P. S. 2018. Perancangan Website Sebagai Media Promosi DanInformasi. Journal Of Informatic Pelita Nusantara, 3(1).

[4] King, R. C., Schilhavy, R. A., Chowa, C., \& Chin, W. W. 2016. Do customers identify with our website? The effects of website identification on repeat purchase intention. International Journal of Electronic Commerce, 20(3), 319-354. 


\section{International Journal of Research and Applied Technology}

1(1)(2021) 43-48

Journal homepage: https://ojs.unikom.ac.id/index.php/injuratech

[5] Priyadarshini, C., Sreejesh, S., \& Anusree, M. R. 2017. Effect of information quality of employment website on attitude toward the website. International Journal of Manpower.Hasanov, Jasur and Khalid, Haliyana. 2015. The Impact of Website Quality on Online Purchase Intention of Organic Food on Malaysia : A Webqual Model Approach.

[6] Chiew, K. L., Chang, E. H., \& Tiong, W. K. 2015. Utilisation of website logo for phishing detection. Computers \& Security, 54, 16-26.

[7] Ladhari, R., \& Michaud, M. 2015. eWOM effects on hotel booking intentions, attitudes, trust, and website perceptions. International Journal of Hospitality Management, 46, 36-45.

[8] Kaur, S., Kaur, K., \& Kaur, P. 2016. An empirical performance evaluation of universities website. International Journal of Computer Applications, 146(15), 10-16.

[9] Taddeo, C., \& Barnes, A. 2016. The school website: Facilitating communication engagement and learning. British Journal of Educational Technology, 47(2), 421-436.

[10] Gupta, S., Borkar, D., De Mello, C., \& Patil, S. 2015. An e-commerce website based chatbot. International Journal of Computer Science and Information Technologies, 6(2), 14831485.

[11] Pangaribuan, I., \& Rahman, A., Mauluddin, S. 2020. Computer \& Network Equipment Management System (CNEMAS) Application Measurement. International Journal of Informatics, Information System and Computer Engineering, 1(1), pp. 25-35. 